\title{
SOCIAL COGNITION. PRACTICAL PSYCHOLOGY OF MANAGEMENT
}

\author{
Takhir Yu. Bazarov \\ Lomonosov Moscow State University
}

Moscow

\begin{abstract}
Management as a form of cognition implies gaining new experience and knowledge, particularly about oneself. Traditionally, the psychology of social cognition distinguishes between an object and a subject of cognition (i.e. the one who cognizes). The subject of cognition can represent both an individual and a social group. As consciousness and mentality of an individual changes in modern society, essential topics of social cognitive psychology assume new importance: society components are becoming inter-cognitive. There is a change in the structure of management relations within the management system that includes aims and functions, as well as the subject and object of management.
\end{abstract}

Keywords: Social cognition, social change, "management space," "manager's selfconcept," "individual management concept," "professional identity," managerial identity.

Social cognitive psychology focuses on four major aspects: general overview of how the social information is processed, determinants of the process, society elements revealed through the process, and social institutions that enable society formation. Contemporary research has increasingly emphasized the fact that a man is an active creator who designs social and individual reality. It entails a new insight on management problematic, which becomes more complex and profound. First of all, the very notion of management is associated with some activity or a certain exposure on an object with its subsequent transformation. Management as a mode of influence and environmental change comes as a social value. Naturally, it is embedded in the social cognition process and exists as a system of ideas and categories used by an individual to define all kinds of social phenomena. Today one may admit the emergence of special "management space," both external and internal. The former is related to the social change and the development of management social 
perception, as well as transformation of organizational and management practices. The latter will address the subject of managerial activity, who may perceive himself as a manager, professional and individual. When we say "management space," we have in mind a certain system of values, and the sphere of social discourse, shaped by real processes both social and individual. This informational space includes a certain supraindividual knowledge of management and its components, an image of a perfect manager, an idea of success and power, professional and role models acquired through concrete activity. Therefore, the whole gamut of these notions that constitute human experience is projected onto each subject of management activity to form the unique pattern of a part of his self-image.

Thus, along with the system of manager's ideas and his managerial identity that includes a number of self-determinations (i.e., judgments made by the subject about himself and his professional management activity), there is a complete set of common knowledge, a primary source which allows an individual to develop a self-image, picking up the most appropriate definitions. Managerial identity defined as a system of ideas would mean an array of self-determining conceptions developed by the synthesis of personal management experience and universal knowledge.

Management as a form of cognition implies gaining new experience and knowledge, about oneself, in particular. Traditionally, the psychology of social cognition distinguishes between an object and a subject of cognition (the one who cognizes). The subject of cognition can represent both an individual and a social group. As consciousness and mentality of an individual changes in contemporary society, essential topics of social cognitive psychology assume new importance: society components are becoming inter-cognitive. For instance, research on social perception, perception of social objects, is currently in the stage of reorientation in terms of its subject matter; the borderline between the subject and the object of perception is shifting. Yet, the self-image remains as one of the results of the process, and joint activity comes as its determinant. There has been a change in the structure of management relations within the management system that includes purposes and functions as well as the subject and object of management. Horizontal relations between colleagues and principles of self-management are frequently preferred to vertical interactions between the manager and the staff. In a broader 
sense, we are observing the transition to the strategy of teamwork with external environment (Bazarov, 2002), i.e. the emphasis is shifted from the human resource as organizational capacity to a team as an intellectual asset.

Being in the management environment as well as living in the society enables an individual to realize and see himself as a subject within the context of relations with external environment including organizational environment and professional field, specifically professional management sphere. Social cognition can be treated both from the scientific point of view and from the position of commonplace. Similarly, management has two aspects: academic and practical. The social cognitive psychology always defines a certain model that helps interpret relations between the person and the world. Selecting a representative of a certain social group as an object of research, and placing him in a narrower context, we may reduce the scope of our analysis, but the model remains the same. Thus, a manager, or, in broader terms, a subject of management activity, being a part of organization also develops his self identity, and some of these ideas about the self that are related to his management experience and organizational membership, can be defined as management and organizational identity.

Diversity of activities that a person in modern world can engage oneself in causes creation of new types of identities. We will focus on the analysis of one of the "products" of social cognition as well as society components as they appear to a cognizing subject. The range of these components is rather wide: self-image, image of the Other, image of the Group (organization), image of Time, image of Environment, etc. (Andreeva, 1999). Let us refer to the very core of this problematic cluster, the self-image of a subject who cognizes the society. According to G.M. Andreeva, the issue of social identity, the self-image, in its certain aspects is the cornerstone of social cognitive psychology (Andreeva, 2002). The truth that started social cognition as an academic concept consists in admitting the unity of cognition and activity: men act in accordance with what they have learnt about the world, and yet they cognize the world in accordance with the way they act (Andreeva, 1999). As self-image is a component of the social world, the self cognition and the process of acquiring identity are inter-correlated with activity. One of the spheres of social life where a person can define and fulfill oneself is professional activity. G.T. Bazarova while analyzing professional identity within the 
context of professional socialization suggested the following definition: "within the scope of social psychology professional identity represents professional identification of a subject through categorization of professional environment and relating oneself to a certain category based on reflexive idea about oneself as a professional" (Bazarova, 2001). Research conducted in this field revealed that the main personality results of successful professional socialization of a manager include his leadership capacity, mastering a range of team roles and the reflexive idea about his professional career (Bazarova, 2001).

L.M. Mitina considers the individual's professional development as growth, formation and integration of personal traits and abilities, professional knowledge and skills through professional activity, and, most important, as an active qualitative transformation of his inner world, which leads to creative self-fulfillment in a profession. The major psychological prerequisite and a form of personal professional development is professional socialization as a process when an individual enters professional environment, acquires professional experience and adopts professional society values as well as actively implements accumulated experience and self-development. Professional socialization is analyzed from substantive, dynamic and institutional points of view (Mitina, 1996).

The study of professional identity is similar to the study of professional self-concept. V.S. Agapov defines the notion of self-concept as systemic, integral and self-organizing formation of mentality. That is a complex, endured, multilevel, multicomponent and dynamic system for expressing one's attitude towards oneself and the external world; the system rooted in evaluative activity of the mind. The author introduces the notion of "a prognostic model of the self-concept," that is a means for detection psychological functions, mechanisms and factors of productive formation of actual self-concept during management activity. This is a dynamic, relatively stable, multilevel and endured hierarchical system, reflecting interaction of conscious and unconscious spheres, relations and values. According to the researcher, formation of the self-concept is indicated by interrelation, integrity and mutual interaction of the following three factors:

1. Content of the self-concept (qualitative characteristics of structure; social and role standing and experience; power, development and methods to reconcile one's needs in achievement, power, and personal authority over events and people, and in affiliation); 
2. Management activity (realization methods and consistency of functional components; assessing style of management decision making; expertise; authority and acts; activity results);

3. Life and events (ways to settle life controversies, consistency in goal achievement, fulfillment and life satisfaction) (Agapov, 1998).

The use of the term "managerial identity" should emphasize the distinction between this identification structure and the following notions: "manager's self-concept," "individual management concept" and "professional identity." Let us outline in brief this specific nature. Unlike "manager's self-concept," managerial identity is not "an identity of a manager," but an identity of a subject of management activity; such an identity is related to self-reflection of management experience. Managerial identity differs from "individual management concept" in its nature focusing on the subject, whereas "individual management concept" is a concept of management, not of oneself. As for professional identity, it is different from managerial identity in that the latter describes broader subjective psychological reality, being some kind of a framework to interpret both professional and personal management experience. Thus, this notion is somewhat broader than professional identity which implies identification with a professional group. There are at least two questions we need to answer in this connection. First of all, whether we can regard the "manager" position as a profession and whether subjects themselves regard it as such. Secondly, whether a person should have managerial identity if his profession only partially consists in performing management functions. The interdisciplinary nature of this topic comes from both the complexity of the very phenomenon of identity and the prevailing character of the management subject matter. The point is that managerial identity has several "substrates." On the one hand, two aspects are traditionally assigned to the notion of identity: personal (individual aspect) and social (group aspect). The contraposition of individual and social aspects is one of the core problems in social psychology and most discussions have come to admit reciprocal influence of these fundamentals. Managerial identity, if social in its essence, has a unique quality that is intensified and emphasized by the specific nature of management as the profession. On the other hand, managerial identity, though it refers to professional sphere, is not just a form of professional identity. 
To begin with, most people that perform management functions do not acknowledge or think of "management" as a profession, they would call it "vocation," "punishment," "life style" or whatever. Besides, management activity is present in various professional spheres and involves mastering of related areas of human experience; therefore this type of identity may certainly be called "trans-professional."

Thus, managerial identity is a complex system of ideas shaped about oneself, it includes a number of self-determinations, i.e. judgments made by the subject about himself and his professional management activity. The managerial identity reveals itself in manager's self-determination in terms of affiliation with a certain organization, team (i.e. social group), self-determination in activity (both professional and management), in adoption of managerial and group roles (repertoire of roles, the position within an organization), as well as in terms of major professional qualities (i.e. qualities that a manager may think he requires to exercise efficient management) (Kuzmina, 2002).

Acquisition of managerial identity is an important part of professional formation for executives and managers. In this context it is appropriate to refer to the process as manager's professional socialization that results in managerial identity. If we turn to research on professional identity, a number of similarities can be observed. For instance, E.P. Ermolaeva marks out two aspects of identities: external and internal (Ermolaeva, 1998). The external aspect of managerial identity, as a part of professional identity, is defined by the way the subject is perceived by others (colleagues, clients, close relatives) and to what extent others accept him as a manager. In accordance with external professional identity, suggested by Ermolaeva, external managerial identity comes as a preconditioned degree of agreement between individual traits and skills and demands made for management activity (agreement between the real self and the ideal self).

This brings us to yet another important issue: to what extent external managerial identity is suggested by reflected evaluations of "authoritative others," or it may come as the result of social conceptions of management and correlation of one's own self-dimensions with the collective image of a subject engaged in management activity. If we accept $K$. Gergen's statement and the theory of social constructionism (according to which an individual and his cognitive processes are actively engaged in designing the social world), then reference to managerial 
identity comes as a means to change this world. In other words, launching the process of self-reflection and actualizing his own identity or his social views, the manager comes to change himself, which means that he starts to transform both subjective and objective, for instance, organizational reality. With all variety of existing images of different people and diversity of those images stored by each individual, all of them would fit into one common pattern, which testifies to the existence of a specific supra-individual process (see Fig. 1).

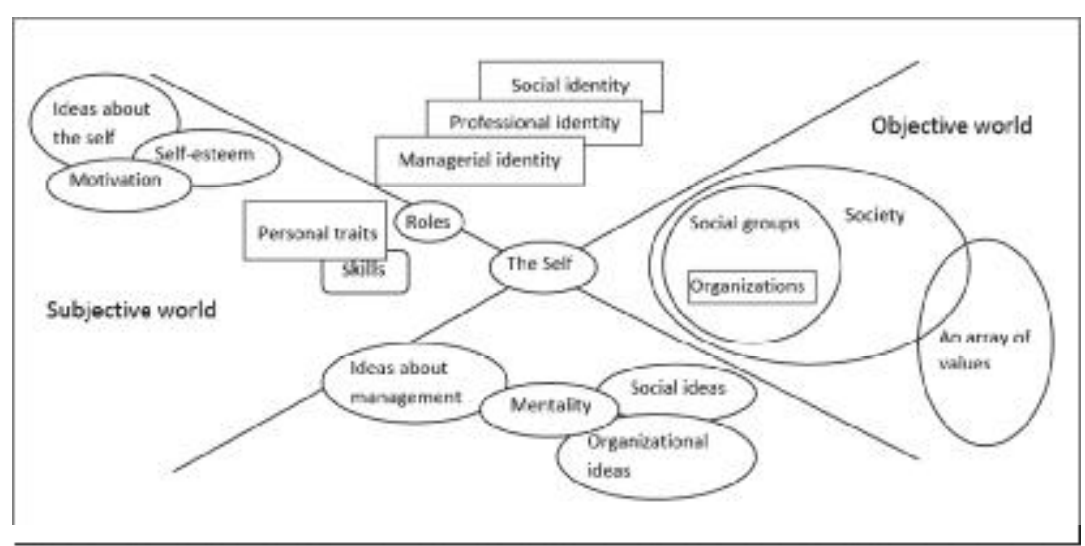

Figure1. Internal and external aspects of managerial identity

The internal aspect of managerial identity includes self-perception and professional and management self-comprehension, i.e. whether one is identifying himself as a professional (in our case as a manager), whether one fits a professional role (management role) and whether he has mastered professional tools (management skills).

The use of the category of activity as an explanatory principle, admits the existence of leading activity within professional socialization. A "substrate" of the basic managerial identity can be represented by either the actual management activity or ideas about it. S. Moscovici defined the social view as a network of ideas, assertions and explanations emerging in everyday interpersonal communication. He regarded the social view as meaningful knowledge, an equivalent to a myth or belief, and a form of cognition of social reality. According to G.M. Andreeva, social views promote the formation of social identity, i.e. they help an individual to 
identify himself with a group and, moreover, to develop his own "group" self-comprehension, perceive himself as an element within the system that has common philosophy and common world view (Andreeva, 2000). The theory of social views as well as the theory of social identity serves as an instrument to comprehend mechanisms of social cognition, in particular "image" development of individual element within the social world. Basically, "manager" is also an image and element of social world. When the question "What am I as a manager?" is answered by the immediate subject of management activity, the subject actualizes his image of a manager. G. Breakwell, who attempted comparison of the two indicated paradigms, believes that the theory of social identity as merged with the theory of social views could shed more light on the importance of identification in the process of designing a social reality (Andreeva, 2000).

The full-fledged managerial identity implies solid self-comprehension as a manager and full recognition of the fact by others. There are at least three factors affecting managerial identity: "the self," "we" and "they": (1) "I consider / do not consider myself a manager" - an internal factor (attributing oneself to some abstract group of managers, not to a certain professional community); (2) "We are managers" - for instance, actual referential group (managers obtaining together a degree in business) or abstract group ("we, managers, are such people that..."); (3) "They (other people - colleagues, friends, etc.) consider me a manager" - an external factor (can be expressed in authority, status and power, both actual and perceived).

Similar to the conventional classification of identity, the managerial identity, it can be assumed, may also be attributed with the status of either attained or diffused one, depending on decisions made by the subject of managerial identity with respect to himself as a manager, management self-evaluation and pivotal trends.

Empirical study of social psychological traits and factors of managerial identity, undertaken for the groups of managers, directors and students (the total number of participants amounted to 188 people), revealed that the phenomenon of managerial identity can be attributed both to the internal personal and unique world of one particular subject and to the external, collective and social world. It is rather difficult to distinguish between these two worlds and tell exactly when an individual's self-determinations can be attributed to the self and when they are 
referring to the outside world and the sphere of social discourse. Such a problem arises from epistemological and social context in which we live and where the boundaries between many points of the opposite nature, which used to be crystal clear, are gradually fading away. Managerial identity as a result of reflection upon management activity and comprehension of personal and social experience, appears as a social psychological phenomenon with its specific structure; it may have some common foundation but can be filled with various content, diversity of qualities, roles and motives; it's very much like painting, no matter how reach it can be in hue-scales, the whole palette will consist of the finite number of colors. Formulating her ideas on social cognitive psychology, G.M. Andreeva refers to the metaphor of J. Mellibruda, that human perception and comprehension would rather remind of the process of painting a picture or directing a movie than recording the audio tape or taking pictures with camera (Andreeva, 2000). Although traditionally identity is defined as a result, it is obvious, and the idea was supported by many authors, that it appears as some kind of a process. Managerial identity is by no means static, it evolves throughout the entire life of a person, as he acquires new knowledge about himself and his professional and management experience. We believe, that the most promising research may be conducted on the dynamic characteristics of managerial identity, to study how it is related to professional socialization, career choice and organizational environment. That would allow us to grasp a deeper understanding of social and psychological factors affecting its structure, content and status.

Thus, there is evident importance in reflection upon personal and management experience for professionals who exercise management of people and groups of people, arrange the process structure, team work, etc. In this respect helping to comprehend one's own "managerial self" is crucial both for acquiring the identity, inner harmony and positive selfesteem, etc., and for increasing work efficiency and improving organizational performance. The prospect of providing this kind of psychological assistance may be applied in a number of directions. Psychotherapeutic help and consulting activity may be applied on the level of personality subject of management activity, in particular the area of coaching that combines various techniques for individual and organizational consulting and development. On the group level, the most efficient method is training work, with both management teams and corporate departments; 
that will allow managers to understand and actualize the resources, get feedback on their management style and specifics of role behavior and interaction with the staff. In order to achieve these goals it is possible to supplement traditional methods and exercises of social psychological training with techniques used with actors and directors, in particular those that deal with mastering and managing role models. On the level of organization, it is relevant to work with organizational development that is associated with organizational identity, corporate culture and mentality, as well as managers' and colleagues' recognition that they are a part of a group and organizational reality; that can be done through various games: strategic, organizational, management, business, etc.

Thus, managerial identity as part of the self-image of a subject cognizing the social world is associated with all components of this world. The image of "the Other" is defined by ideas about "other" managers and includes various characteristics of an ideal manager, stereotypes and management models. The image of "the Group" is recreated through identifying oneself with a team, division and organization. The image of Time is represented by time measurement of managerial identity: retrospective ("the Self in the past"); possible or potential ("the Self in the future"): "possible ideal Self," "possible actual Self," as well as possible organizational identity. Thus, it is the sphere of social cognitive psychology that can answer many questions related to managerial identity topics. Further research and study of indicated areas are necessary in order to find more accurate definition for social and psychological status of the phenomenon.

\section{References}

Agapov, V.S. (1998). Stanovlenie Â-koncepcii v upravlenčeskoj deâtel'nosti rukovoditelâ (Candidate of Sciences dissertation). Moscow.

Andreeva, G.M. (1999). K problematike psihologii social'nogo poznaniâ. Mir psihologii, 3, 15-23.

Andreeva, G.M. (2000). Psihologiâ social'nogo poznaniâ. Moscow: Aspekt Press.

Andreeva, G.M. (2002). Trudnosti social'nogo poznaniâ: "obraz mira" ili real'nyj mir. In G.M. Andreeva \& A.I. Dontsov (Eds.), Social'naâ psihologiâ v sovremennom mire (pp. 182-198). Moscow: Aspekt Press.

Bazarov, T.Yu. (2002). Mif o večnom vozvraŝenii. HR-menedžer - sozercatel' ili upravlâûsîij? So-obsenenie, 6 . 
Bazarov, T.Yu. (2002). Upravlenčeskie tehnologii: problemy organizacionnogo razvitiâ. In G.M. Andreeva \& A.I. Dontsov (Eds.), Social'naâ psihologiâ v sovremennom mire (pp. 238-257). Moscow: Aspekt Press.

Bazarova, G.T. (2001). Social'no-psihologičeskie faktory professional'noj socializacii menedžera (Candidate of Sciences dissertation). Moscow.

Ermolaeva, E.P. (1998). Professional'naâ identičnost' kak kompleksnaâ harakteristika sootvetstviâ sub»ekta i deâtel'nosti. Psihologičeskoe obozrenie, 2, 35-45.

Kuzmina, M.Yu. (2002). Upravlenčeskaâ identičnost' rukovoditelâ. Ežegodnik RPO. Psihologiâ i eë priloženiâ, 9 (3).

Mitina, L.M. (Ed.). (1996). Problemy professionalnoj socializacii ličnosti. Kemerovo: KOIUU. 